\title{
IDENTIFYING THE REFERENCE TIME FOR DETERMINING THE COMPRESSIVE STRENGTH OF CONCRETE CONTAINING DIFFERENT TYPES OF CEMENTS
}

\begin{abstract}
Anca IONESCU - Assistant professor, Technical University of Civil Engineering, Faculty of Civil, Industrial and Agricultural Buildings, e-mail: ionescuanca@yahoo.com;

Adelina APOSTU - Physicist, PhD, Technical University of Civil Engineering, Faculty of Civil, Industrial and Agricultural Buildings, e-mail: adelina.apostu@yahoo.com;

Dan Paul GEORGESCU - professor, PhD, Technical University of Civil Engineering, Faculty of Civil, Industrial and Agricultural Buildings, e-mail: danpaulgeorgescu@yahoo.com
\end{abstract}

\begin{abstract}
The compressive strength of the concrete measured at 28 days is the criterion for assessing the concrete class, and these values will be acceptable precise indications for other physical and mechanical characteristics of the concrete. In addition to the factors the compressive strength of concrete varies on (such as: the characteristics and proportion of constituents, the placement conditions and subsequent treatment and testing conditions), the concrete class should also depend on the type of cement contained and the concrete strength evolution over time. Due to the fact that concretes with composite cements have a slower evolution of compressive strength and a significant strength increase after 28 days, concretes with different types of cements and mineral admixtures were tested for compression after 28 days in order to determine the reference time for such tests and thus the concrete's class.
\end{abstract}

Keywords: concrete, compressive strength of concrete, cement with mineral additions, reference time.

\section{Introduction}

The experimental results showed that the compressive strength of the concrete and its evolution over time are influenced by a series of parameters, calculating formulae being thus proposed in the designing codes. Additional cementing materials introduced within the cement or concrete (such as: siliceous or calcite flying ashes, ground granulated furnace slag or calcareous filler), give the concrete mechanical properties that are different to those of concrete prepared with Portland cement. These mineral additions within the concrete, due to their chemical, physical and mineralogical properties, have an influence on the hydrating reactions, on the evolution of the structure of the pores and on the composition of the solutions in the pores, causing alterations in the concrete's microstructure, thus influencing the performance of the material inside the concrete structures exposed to environmental conditions. This paper refers to the influences of these mineral additions on the evolution in time of concrete's strengths prepared with different types of cements.

\section{Theoretical presentation of European Standard SR EN 1992-1-1 and the new Draft prEN 1992-1-1.}

Although based on principles in use for a long period of time, the current provisions of European Standard SR EN 1992-1-1 [1] - describing the evolution over time of the compressive strength of concrete - lead to results sometimes different from reality.

The following formulae are used to determine the strength for concrete of ages other than 28 days:

$$
\begin{aligned}
& \mathrm{fck}(\mathrm{t})=\mathrm{fcm}(\mathrm{t})-8 \mathrm{MPa} \quad \text { for } 3<\mathrm{t}<28 \text { days } \\
& \mathrm{fck}(\mathrm{t})=\mathrm{fck} \quad \text { for } \mathrm{t} \geq 28 \text { days }
\end{aligned}
$$

where the average compressive strength at age " $\mathrm{t}$ " is estimated by the formulae:

$$
\begin{aligned}
& \mathrm{f}_{\mathrm{cm}}(\mathrm{t})=\beta_{\mathrm{cc}}(\mathrm{t}) \times \mathrm{f}_{\mathrm{cm}} \\
& \beta_{\mathrm{cc}}(\mathrm{t})=\exp \left\{\mathrm{s}\left[1-(28 / \mathrm{t})^{1 / 2}\right]\right\}
\end{aligned}
$$


where :

$f_{c m}(t)$ is the average compressive strength of concrete at " $t$ " days of age;

$\mathrm{f}_{\mathrm{cm}}$ - average compressive strength of concrete at 28 days;

$\beta_{\mathrm{cc}}(\mathrm{t})$ - coefficient depending on the concrete's age;

$\mathrm{t}$ - concrete's age, in days;

$\mathrm{s}$ - coefficient depending on the type of cement.

$\mathrm{s}=0.20$ for CEM 42.5R, CEM 52.5N and CEM 52.5R (class $\mathrm{R}$ )

$\mathrm{s}=0.25$ for CEM $32.5 \mathrm{R}$ and CEM $42.5 \mathrm{~N}$ (class $\mathrm{N}$ )

$\mathrm{s}=0.38$ for CEM $32.5 \mathrm{~N}$ (class $\mathrm{S}$ )

The current standard considers only the cement's strength class within the concrete - by using "s" coefficient, the temperature and subsequent treatment conditions - and average compressive strength of the concrete at 28 days. This new project, aiming to update the European standard prEN 1992-1-1 [2] (drafted in October 2017), brings in new values for "s" coefficient and the possible taking into consideration the reference time of 28 to 90 days for determining the evolution in time of concrete's compressive strength. Based on this, in our proposal of revising prEN 1992-1-1 [2] standard, the characteristics for compressive strength of concrete (which defines the strength classes) is to be determined at a reference time generally considered to be 28 days, or between 28 91 days for applications where strength develops slowly. Thus, according to this revising project, the average compressive strength of concrete at different ages $\mathrm{fcm}(\mathrm{t})$ can be estimated by the following formulae:

where:

$$
\begin{aligned}
& \mathrm{f}_{\mathrm{ck}}(\mathrm{t})=\mathrm{f}_{\mathrm{cm}}(\mathrm{t})-8 \mathrm{MPa} \quad \text { for } \mathrm{t}<\mathrm{t} \text { ref }(\text { days }) \\
& \mathrm{f}_{\mathrm{cm}}(\mathrm{t})=\beta_{\mathrm{cc}}(\mathrm{t}) \times \mathrm{f}_{\mathrm{cm}} \\
& \beta_{\mathrm{cc}}(\mathrm{t})=\exp \left\{\mathrm{s}\left[1-\left(\mathrm{t}_{\mathrm{ref}} / \mathrm{t}\right)^{1 / 2}\right]\left(28 / \mathrm{t}_{\mathrm{ref}}\right)^{1 / 2}\right\}
\end{aligned}
$$

$f_{c m}(t)$ - is the average compressive strength of concrete at " $t$ " days of age;

$\mathrm{f}_{\mathrm{cm}}$ - average compressive strength of concrete at age 28 days;

$\beta c c(t)$ - coefficient depending on the age of the concrete;

$\mathrm{t}$ - age of concrete, in days;

tref - age of concrete at which the concrete strength is determined in days;

$\mathrm{s}$ - coefficient depending on the type of cement.

Table 1

Values of coefficient $s$ for different cements and classes of concrete ( prEN 1992-1-1 [2] )

\begin{tabular}{|l|c|c|c|}
\hline \multicolumn{1}{|c|}{ Concrete class } & $\begin{array}{c}\text { High early strength } \\
\text { Class R }\end{array}$ & $\begin{array}{c}\text { Ordinary early strength } \\
\text { Class N }\end{array}$ & $\begin{array}{c}\text { Low early strength } \\
\text { Class L }\end{array}$ \\
\hline & $\begin{array}{c}\text { Cement of strength CEM } \\
42.5 \mathrm{R}, \text { CEM 52.5N and CEM } \\
52.5 \mathrm{R}\end{array}$ & $\begin{array}{c}\text { Cement of strength CEM } \\
\text { 32.5R, CEM 42.5N }\end{array}$ & $\begin{array}{c}\text { Cement of strength } \\
\text { CEM 32.5N }\end{array}$ \\
\hline C35 and below & 0.3 & 0.35 & 0.4 \\
\hline C40-C55 & 0.2 & 0.25 & 0.35 \\
\hline C60 and above & 0.1 & 0.17 & 0.3 \\
\hline
\end{tabular}

The different approaches between the two editions of the standard reveal that evolution of concrete's strength depends over time, taking into consideration that - in case of some compositions with types of cement with slow evolving strength - other time of reference can be acceptable rather than the 28 days one. 


\section{Case Study}

In order to analyze the conditions for applying the proposed formula for this new version of the prEN 1992-1-1 standard, a series of concretes with cements containing different percentages of granular furnace slag (with/without flying ash) were tested at different ages. The experimental program aimed to determine the average compressive strength of concretes prepared with four types of cements (one - normal hardening, and three - fast hardening) with a similar w/c ratio. The compositions of concretes are shown in Table 2.

Table 2

Composition and properties of fresh concrete prepared with CEM II/B-S 32.5R, CEM II/B-S 32.5N, CEM II/B-M (S-V) 32.5R and CEM III/A 32.5R

\begin{tabular}{|l|c|c|c|l|c|}
\hline \multicolumn{1}{|c|}{ Cement type } & w/c ratio & $\begin{array}{c}\text { Cement } \\
\text { dosage } \\
\left(\mathrm{kg} / \mathrm{m}^{3}\right)\end{array}$ & $\begin{array}{c}\text { Maximum diameter } \\
\text { of the aggregate } \\
(\mathrm{mm})\end{array}$ & \multicolumn{1}{|c|}{ Admixture } & $\begin{array}{c}\text { Settlement } \\
(\mathrm{mm})\end{array}$ \\
\hline CEM II/B-S 32.5R & 0.44 & 360 & 32 & superplasticizer admixture & 110 \\
\hline CEM II/B-S 32.5N & 0.42 & 420 & 16 & $\begin{array}{l}\text { superplasticizer and air- } \\
\text { entrain admixture }\end{array}$ & 150 \\
\hline $\begin{array}{l}\text { CEM II/B-M } \\
\text { (S-V) 32.5R }\end{array}$ & 0.43 & 370 & 32 & superplasticizer admixture & 115 \\
\hline CEM III/A 32.5R & 0.41 & 370 & 32 & superplasticizer admixture & 110 \\
\hline
\end{tabular}

Figures 1 and 1 ' show the experimental results for average compressive strength measured at different ages for these four concrete compositions (containing different types of cement). The evolution of compressive strengths of concrete with CEM II/BS 32.5R, CEM II/BS 32.5N, CEM II/BM (SV) 32.5R and CEM III/A 32.5R was also analyzed over time by comparing the results experimentally obtained versus the computed strength values as per the designing prescriptions in SR EN 1992-1-1: 2004 [1] and as per the Project for revising EN 1992-1-1 [2] (taking into account in this case, different reference ages - 28, 56 and 90 days).

\begin{tabular}{|c|c|c|c|c|c|}
\hline \multirow{7}{*}{ 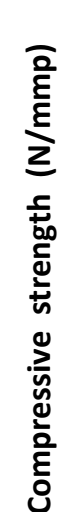 } & \multirow{3}{*}{$\begin{array}{l}80 \\
70 \\
60\end{array}$} & & & & \\
\hline & & & & & \\
\hline & & & & & \\
\hline & 40 & & & & \\
\hline & 30 & & & & \\
\hline & \multirow{3}{*}{$\begin{array}{r}20 \\
10 \\
0\end{array}$} & & & & \\
\hline & & & & & \\
\hline & & $\begin{array}{c}\text { CEM II/B-S } \\
32.5 \mathrm{R}\end{array}$ & $\begin{array}{c}\text { CEM II/B-S } \\
32.5 \mathrm{~N}\end{array}$ & $\begin{array}{c}\text { CEM II/B-M } \\
32.5 \mathrm{R}\end{array}$ & $\begin{array}{c}\text { CEM III/A } \\
32.5 \mathrm{R}\end{array}$ \\
\hline \multicolumn{2}{|c|}{7 days } & 25.55 & & 32.66 & 29.33 \\
\hline \multicolumn{2}{|c|}{28 days } & 36.44 & 54.54 & 43.1 & 47.11 \\
\hline \multicolumn{2}{|c|}{56 days } & 38.08 & 64.29 & 45.24 & 50.25 \\
\hline \multicolumn{2}{|c|}{90 days } & 40.07 & 66.36 & 47.84 & 54.07 \\
\hline \multicolumn{2}{|c|}{180 days } & 47.4 & 68.03 & 49.33 & 54.22 \\
\hline \multicolumn{2}{|c|}{360 days } & 53.33 & 70.39 & 51.4 & \\
\hline \multicolumn{2}{|c|}{720 days } & 56.52 & & 54.67 & \\
\hline
\end{tabular}

Fig. 1 - The variation of compressive strength over time - for concretes containing different types of cement (CEM II/B-S 32.5R, CEM II/B-S 32.5N, CEM II/B-M (S-V) 32.5R and CEM III/A 32.5R) with a w/c ratio of $\sim 0.42$ 


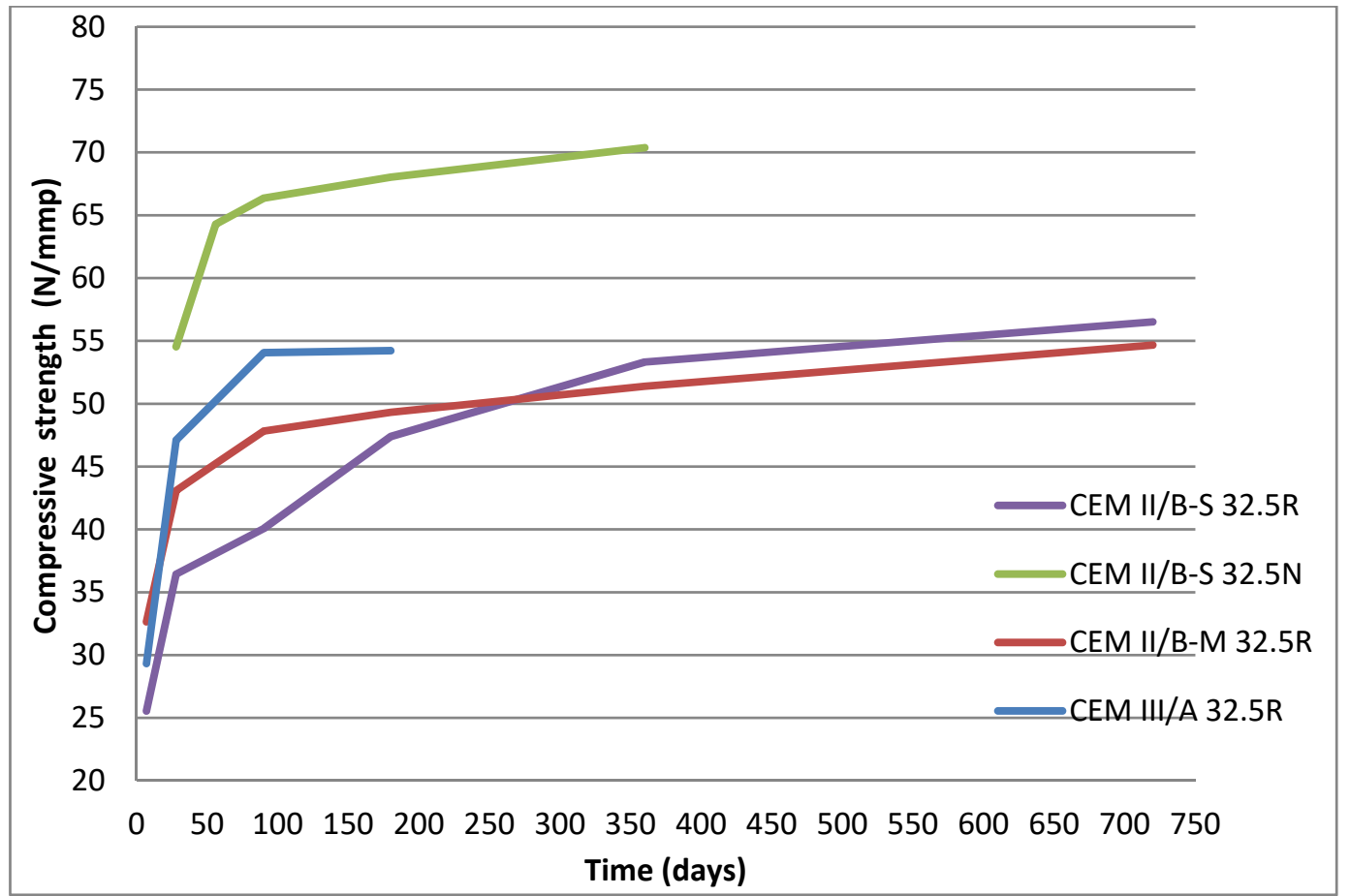

Fig. 1' - The variation of compressive strength over time - for concretes with CEM II/B-S 32.5R, CEM II/B-S $32.5 \mathrm{~N}, \mathrm{CEM}$ II/B-M (S-V) 32.5R and CEM III/A 32.5R and with a w/c ratio of $\sim 0.42$

Table 3

Compressive strength over time - determined experimentally and also calculated - for concrete with CEM II/B-S 32.5R with a w/c ratio of 0.44 [3], [4], [5], [6].

\begin{tabular}{|c|c|c|c|c|c|}
\hline $\begin{array}{l}\text { Age of } \\
\text { concrete }\end{array}$ & $\begin{array}{c}\mathrm{f}_{\mathrm{cm}} \\
\text { experimental } \\
\text { values } \\
(\mathrm{w} / \mathrm{c}=0.44)\end{array}$ & $\begin{array}{c}\mathrm{f}_{\mathrm{cm}}(\mathrm{EC} 2) \\
\text { calculated values }\end{array}$ & $\begin{array}{c}\mathrm{f}_{\mathrm{cm}}(\mathrm{prEC} 2 * \text { ref } 28) \\
\text { calculated values }\end{array}$ & $\begin{array}{c}\mathrm{f}_{\mathrm{cm}}(\operatorname{prEC} 2 * \text { ref } 56) \\
\text { calculated values }\end{array}$ & $\begin{array}{c}\mathrm{f}_{\mathrm{cm}}(\mathrm{prEC} 2 * \text { ref } 90) \\
\text { calculated values }\end{array}$ \\
\hline 7 days & 25.75 & & & & \\
\hline 28 days & 36.44 & & & & \\
\hline 56 days & 38.08 & $\begin{array}{l}\beta=1.076 \\
39.21\end{array}$ & $\begin{array}{l}\beta=1.108 \\
40.37\end{array}$ & & \\
\hline 90 days & 40.07 & $\begin{array}{l}\beta=1.117 \\
40.70\end{array}$ & $\begin{array}{l}\beta=1.167 \\
42.54\end{array}$ & $\begin{array}{l}\beta=1.054 \\
40.12\end{array}$ & \\
\hline 180 days & 47.40 & $\begin{array}{l}\beta=1.163 \\
42.40\end{array}$ & $\begin{array}{l}\beta=1.236 \\
45.04\end{array}$ & $\begin{array}{l}\beta=1.116 \\
42.48\end{array}$ & $\begin{array}{l}\beta=1.059 \\
42.43\end{array}$ \\
\hline 360 days & 53.33 & $\begin{array}{l}\beta=1.197 \\
43.64\end{array}$ & $\begin{array}{l}\beta=1.287 \\
46.90\end{array}$ & $\begin{array}{l}\beta=1.162 \\
44.24\end{array}$ & $\begin{array}{l}\beta=1.103 \\
44.18\end{array}$ \\
\hline 720 days & 56.52 & $\begin{array}{l}\beta=1.222 \\
44.54\end{array}$ & $\begin{array}{l}\beta=1.324 \\
48.26\end{array}$ & $\begin{array}{l}\beta=1.195 \\
45.52\end{array}$ & $\begin{array}{l}\beta=1.135 \\
45.46\end{array}$ \\
\hline & & $\begin{array}{l}\beta_{\max }=1.284 \\
46.79\end{array}$ & $\begin{array}{l}\beta_{\max }=1.420 \\
51.71\end{array}$ & $\begin{array}{l}\beta_{\max }=1.281 \\
48.77\end{array}$ & $\begin{array}{l}\beta_{\max }=1.216 \\
48.71\end{array}$ \\
\hline
\end{tabular}

Denotations:

$f_{\mathrm{cm}}$ (EC 2) - the average compressive strength at an age of over 28 days, calculated as per SR EN 1992-1-1: 2004 [1], with a reference time of 28 days;

$\mathrm{f}_{\mathrm{cm}}$ (prEC $2 *$ ref 28$)$ - the average compressive strength at an age of over 28 days, calculated as per prEN 1992-1-1 [2] draft review, with a reference time of 28 days;

$\mathrm{f}_{\mathrm{cm}}$ (prEC $2 *$ ref 56) - the average compressive strength at an age of over 28 days, calculated as per prEN 1992-1-1 [2] draft review, with a reference time of 56 days;

$\mathrm{f}_{\mathrm{cm}}$ (prEC $2 *$ ref 90 ) - the average compressive strength at an age of over 28 days calculated as per prEN 1992-1-1 [2] draft review, with a reference time of 90 days; 
Table 4

Compressive strength over time - determined experimentally and also calculated - for concrete with CEM II/B-S 32.5N with a w/c ratio of 0.42 [3], [4], [5], [6].

\begin{tabular}{|c|c|c|c|c|c|}
\hline $\begin{array}{c}\text { Age of } \\
\text { concrete }\end{array}$ & $\begin{array}{c}\mathrm{f}_{\mathrm{cm}} \\
\text { experiment } \\
\text { al values } \\
(\mathrm{w} / \mathrm{c}=0.42)\end{array}$ & $\begin{array}{c}\mathrm{f}_{\mathrm{cm}}(\mathrm{EC} 2) \\
\text { calculated values }\end{array}$ & $\begin{array}{l}f_{\mathrm{cm}}(\mathrm{prEC} 2 * \mathrm{ref} 28) \\
\text { calculated values }\end{array}$ & $\begin{array}{l}\mathrm{f}_{\mathrm{cm}}(\mathrm{prEC} 2 * \text { ref } 56) \\
\text { calculated values }\end{array}$ & $\begin{array}{c}\mathrm{f}_{\mathrm{cm}}(\operatorname{prEC} 2 * \text { ref } \\
90) \\
\text { calculated values }\end{array}$ \\
\hline 2 days & 15.00 & & & & \\
\hline 28 days & 54.54 & & & & \\
\hline 56 days & 64.29 & $\begin{array}{l}\beta=1.128 \\
61.52\end{array}$ & $\begin{array}{l}\beta=1.135 \\
61.91\end{array}$ & & \\
\hline 90 days & 66.36 & $\begin{array}{l}\beta=1.183 \\
64.52\end{array}$ & $\begin{array}{l}\beta=1.194 \\
65.09\end{array}$ & $\begin{array}{l}\beta=1.051 \\
67.59\end{array}$ & \\
\hline 180 days & 68.03 & $\begin{array}{l}\beta=1.259 \\
68.65\end{array}$ & $\begin{array}{l}\beta=1.274 \\
69.49\end{array}$ & $\begin{array}{l}\beta=1.122 \\
72.16\end{array}$ & $\begin{array}{l}\beta=1.068 \\
70.84\end{array}$ \\
\hline 360 days & 70.39 & $\begin{array}{l}\beta=1.315 \\
71.73\end{array}$ & $\begin{array}{l}\beta=1.334 \\
72.77\end{array}$ & $\begin{array}{l}\beta=1.176 \\
75.57\end{array}$ & $\begin{array}{l}\beta=1.118 \\
74.19\end{array}$ \\
\hline & & $\begin{array}{l}\beta_{\max }=1.462 \\
79.75\end{array}$ & $\begin{array}{l}\beta_{\max }=1.492 \\
81.36\end{array}$ & $\begin{array}{l}\beta_{\max }=1.314 \\
84.49\end{array}$ & $\begin{array}{l}\beta_{\max }=1.250 \\
82.94\end{array}$ \\
\hline
\end{tabular}

Table 5

Compressive strength over time - determined experimentally and also calculated - for concrete with CEM II/B-M (S-V) 32.5R at w/c ratio of 0.43 [3], [4], [5], [6]

\begin{tabular}{|c|c|c|c|c|c|}
\hline $\begin{array}{l}\text { Age of } \\
\text { concrete }\end{array}$ & $\begin{array}{c}\mathrm{f}_{\mathrm{cm}} \\
\text { experimental } \\
\text { values } \\
(\mathrm{w} / \mathrm{c}=0.43) \\
\end{array}$ & $\begin{array}{c}\mathrm{f}_{\mathrm{cm}}(\mathrm{EC} 2) \\
\text { calculated values }\end{array}$ & $\begin{array}{l}f_{\mathrm{cm}}(\mathrm{prEC} 2 * \text { ref } 28) \\
\text { calculated values }\end{array}$ & $\begin{array}{c}\mathrm{f}_{\mathrm{cm}}(\operatorname{prEC} 2 * \text { ref } 56) \\
\text { calculated values }\end{array}$ & $\begin{array}{c}\mathrm{f}_{\mathrm{cm}}(\mathrm{prEC} 2 * \mathrm{ref} 90) \\
\text { calculated values }\end{array}$ \\
\hline 7 days & 32.66 & & & & \\
\hline 28 days & 43.10 & & & & \\
\hline 56 days & 45.24 & $\begin{array}{l}\beta=1.076 \\
46.37\end{array}$ & $\begin{array}{l}\beta=1.108 \\
47.75\end{array}$ & & \\
\hline 90 days & 47.84 & $\begin{array}{l}\beta=1.117 \\
48.14\end{array}$ & $\begin{array}{l}\beta=1.167 \\
50.31\end{array}$ & $\begin{array}{l}\beta=1.054 \\
47.66\end{array}$ & \\
\hline 180 days & 49.33 & $\begin{array}{l}\beta=1.163 \\
50.14\end{array}$ & $\begin{array}{l}\beta=1.236 \\
53.27\end{array}$ & $\begin{array}{l}\beta=1.116 \\
50.47\end{array}$ & $\begin{array}{l}\beta=1.059 \\
50.65\end{array}$ \\
\hline 360 days & 51.40 & $\begin{array}{l}\beta=1.198 \\
51.61\end{array}$ & $\begin{array}{l}\beta=1.287 \\
55.47\end{array}$ & $\begin{array}{l}\beta=1.162 \\
52.55\end{array}$ & $\begin{array}{l}\beta=1.103 \\
52.74\end{array}$ \\
\hline 720 days & 54.67 & $\begin{array}{l}\beta=1.222 \\
52.68\end{array}$ & $\begin{array}{l}\beta=1.324 \\
57.08\end{array}$ & $\begin{array}{l}\beta=1.195 \\
54.08\end{array}$ & $\begin{array}{l}\beta=1.135 \\
54.27\end{array}$ \\
\hline & & $\begin{array}{l}\beta_{\max }=1.284 \\
55.34\end{array}$ & $\begin{array}{l}\beta_{\max }=1.419 \\
61.16\end{array}$ & $\begin{array}{l}\beta_{\max }=1.281 \\
57.94\end{array}$ & $\begin{array}{l}\beta_{\max }=1.216 \\
58.15\end{array}$ \\
\hline
\end{tabular}

Table 6

Compressive strength over time - determined experimentally and also calculated - for concrete with CEM III/A 32.5 $\mathrm{R}$ at w/c ratio of 0.41 [3], [4], [5], [6]

\begin{tabular}{|c|c|c|c|c|c|}
\hline $\begin{array}{c}\text { Age of } \\
\text { concret } \\
\text { e }\end{array}$ & $\begin{array}{c}\mathrm{f}_{\mathrm{cm}} \\
\text { experimental } \\
\text { values } \\
(\mathrm{w} / \mathrm{c}=0.41)\end{array}$ & $\begin{array}{c}\mathrm{f}_{\mathrm{cm}}(\mathrm{EC} 2) \\
\text { calculated values }\end{array}$ & $\begin{array}{l}\mathrm{f}_{\mathrm{cm}}(\mathrm{prEC} 2 * \text { ref } 28) \\
\text { calculated values }\end{array}$ & $\begin{array}{c}\mathrm{f}_{\mathrm{cm}}(\mathrm{prEC} 2 * \text { ref } 56) \\
\text { calculated values }\end{array}$ & $\begin{array}{c}\mathrm{f}_{\mathrm{cm}}(\mathrm{prEC} 2 * \text { ref } 90) \\
\text { calculated values }\end{array}$ \\
\hline 7 days & 29.33 & & & & \\
\hline 28 days & 47.11 & & & & \\
\hline 56 days & 50.25 & $\begin{array}{l}\beta=1.076 \\
50.69\end{array}$ & $\begin{array}{l}\beta=1.108 \\
52.19\end{array}$ & & \\
\hline 90 days & 54.07 & $\begin{array}{l}\beta=1.117 \\
52.62\end{array}$ & $\begin{array}{l}\beta=1.167 \\
54.99\end{array}$ & $\begin{array}{l}\beta=1.054 \\
52.94\end{array}$ & \\
\hline $\begin{array}{l}180 \\
\text { days }\end{array}$ & 54.22 & $\begin{array}{l}\beta=1.163 \\
54.81\end{array}$ & $\begin{array}{l}\beta=1.236 \\
58.23\end{array}$ & $\begin{array}{l}\beta=1.1157 \\
56.06\end{array}$ & $\begin{array}{l}\beta=1.059 \\
57.25\end{array}$ \\
\hline & & $\begin{array}{l}\beta_{\max }=1.284 \\
60.49\end{array}$ & $\begin{array}{l}\beta_{\max }=1.419 \\
66.85\end{array}$ & $\begin{array}{l}\beta_{\max }=1.281 \\
64.36\end{array}$ & $\begin{array}{l}\beta_{\max }=1.216 \\
65.72\end{array}$ \\
\hline
\end{tabular}


Tables 3-6 show that the values of $\beta$ coefficient in SR EN 1992-1-1:2004 [1] are different from those proposed by the revised European Standard prEN1992-1-1 [2], and therefore the calculated values of compressive strengths of concrete vary in relation to the average compressive strength at 28 days.

Figures 2-5 show the evolution over time of compressive strength (both real and estimated), for the four types of concrete.

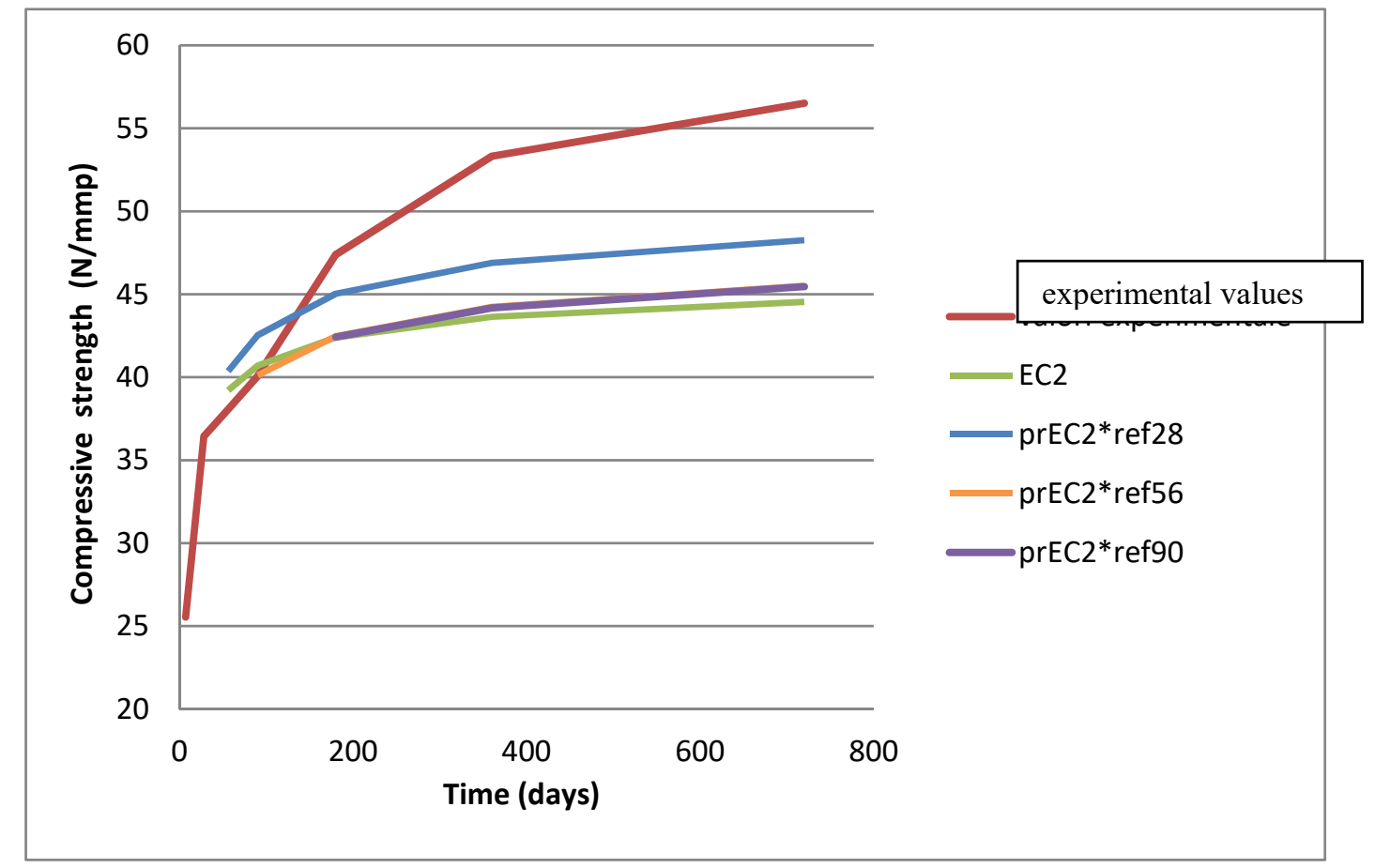

Fig. 2 - Compressive strength of concrete with CEM II/B-S 32.5R with a w/c ratio of 0.44, depending on the age [6].

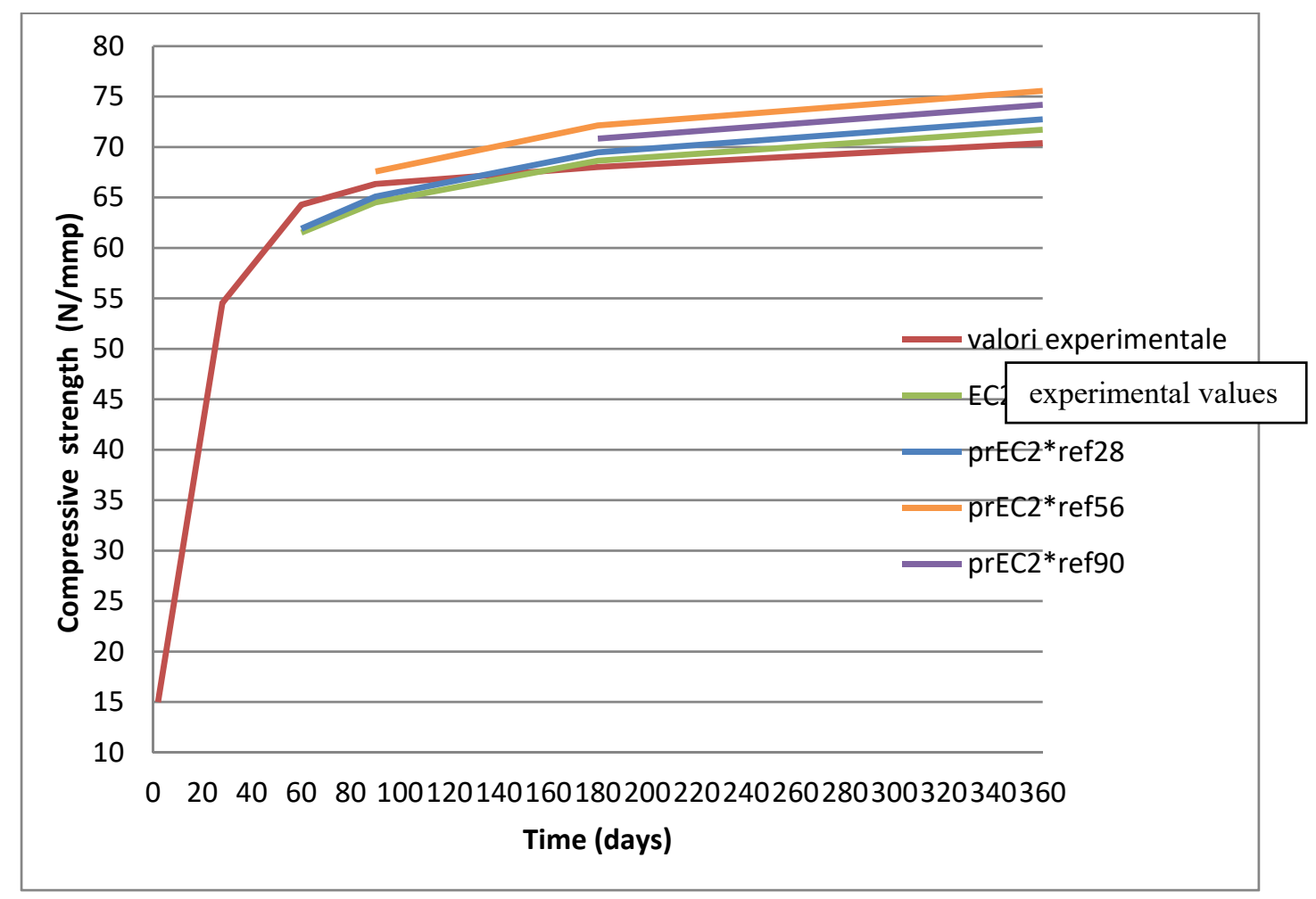

Fig. 3 - Compressive strength of concrete with CEM II/B-S 32.5N with a w/c ratio of 0.42 , depending on age [6]. 


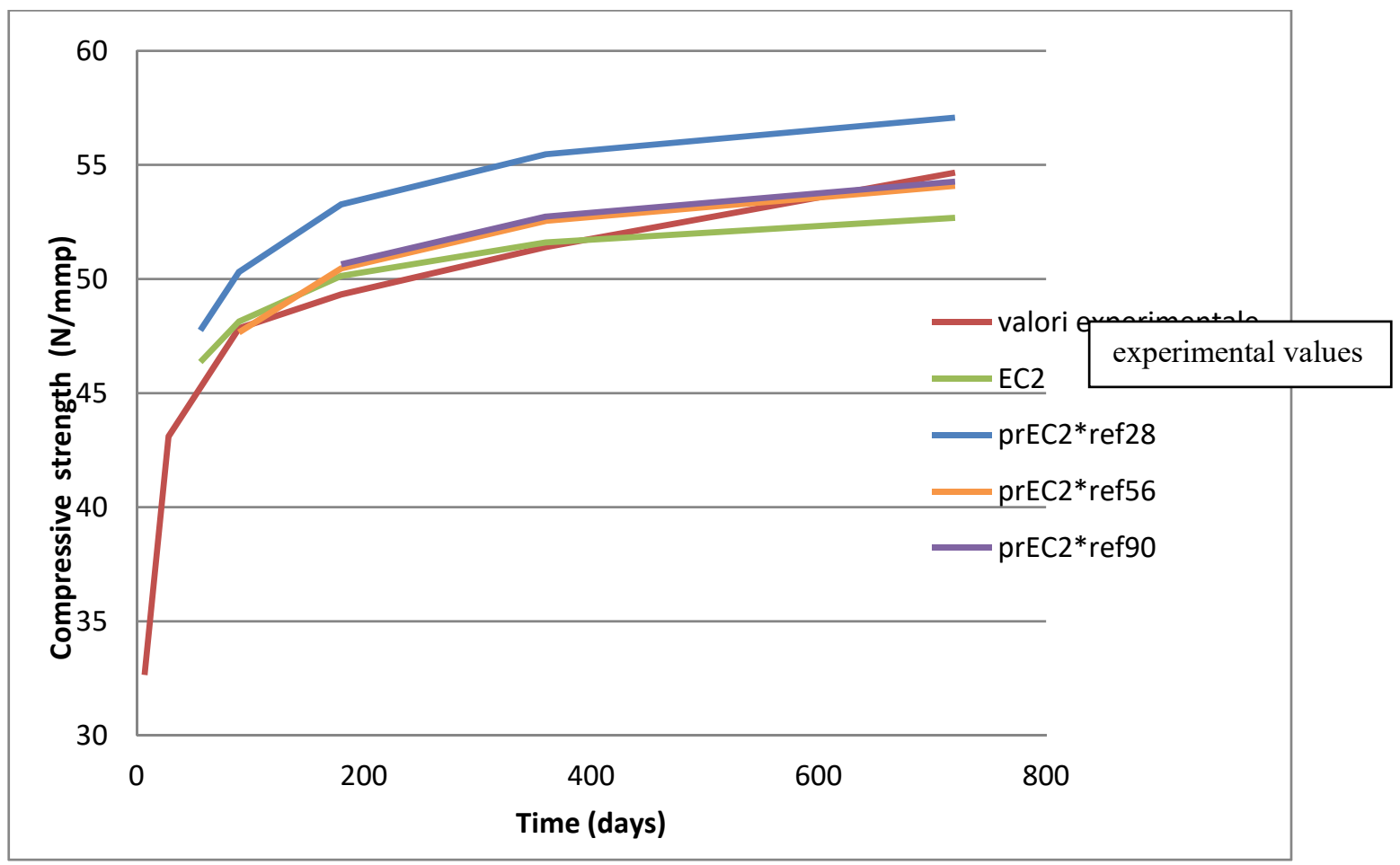

Fig. 4 - Compressive strength of concrete with CEM II/B-M (S-V) 32.5R with a w/c ratio of 0.43, depending on age [6].

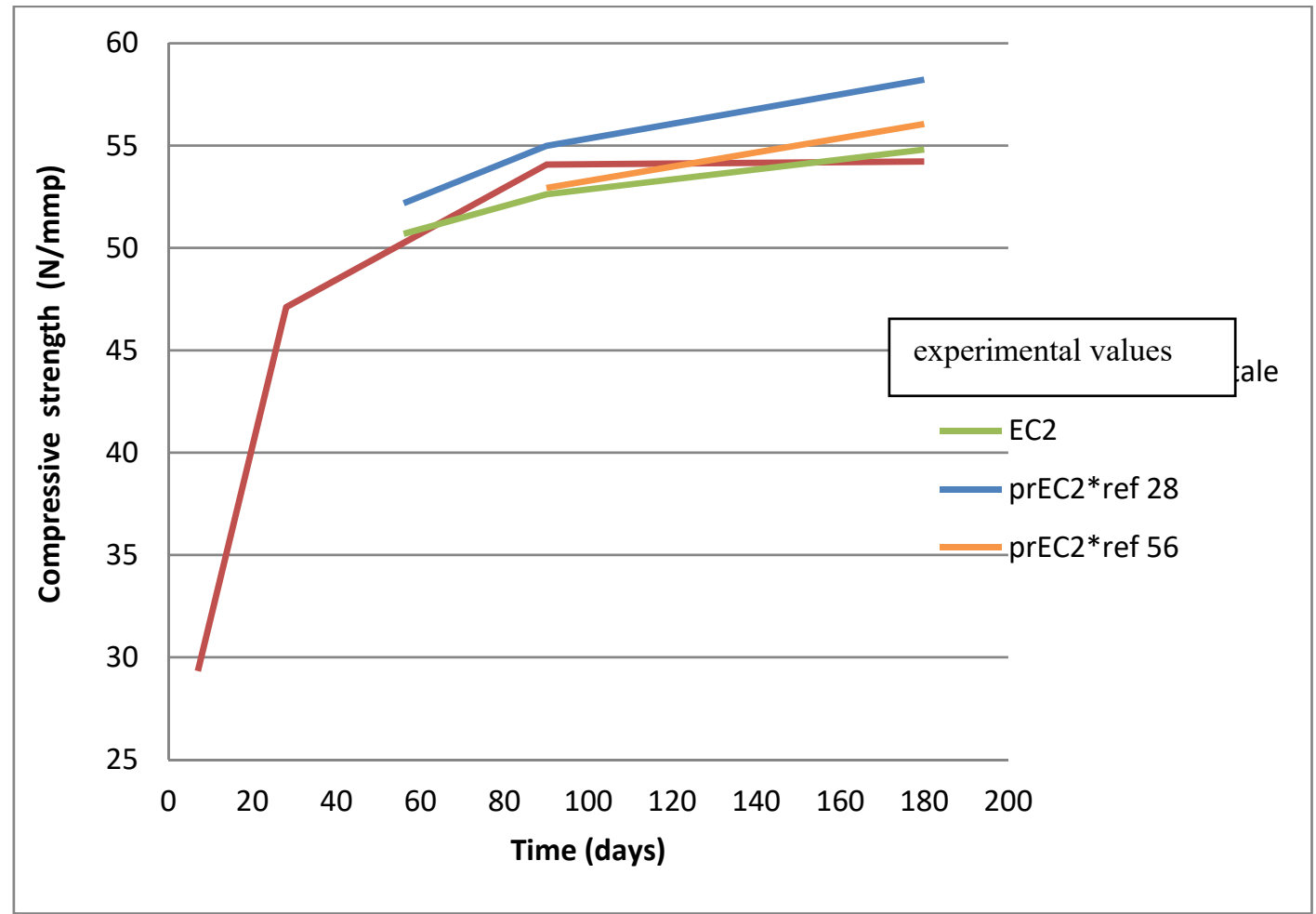

Fig. 5 - Compressive strength of concrete with CEM III/A 32.5R with a w/c ratio of 0.41 , depending on age [6].

Figures 6-8 show the ratios between of compressive strengths for concrete prepared with different type of cements at different proposed reference times. 


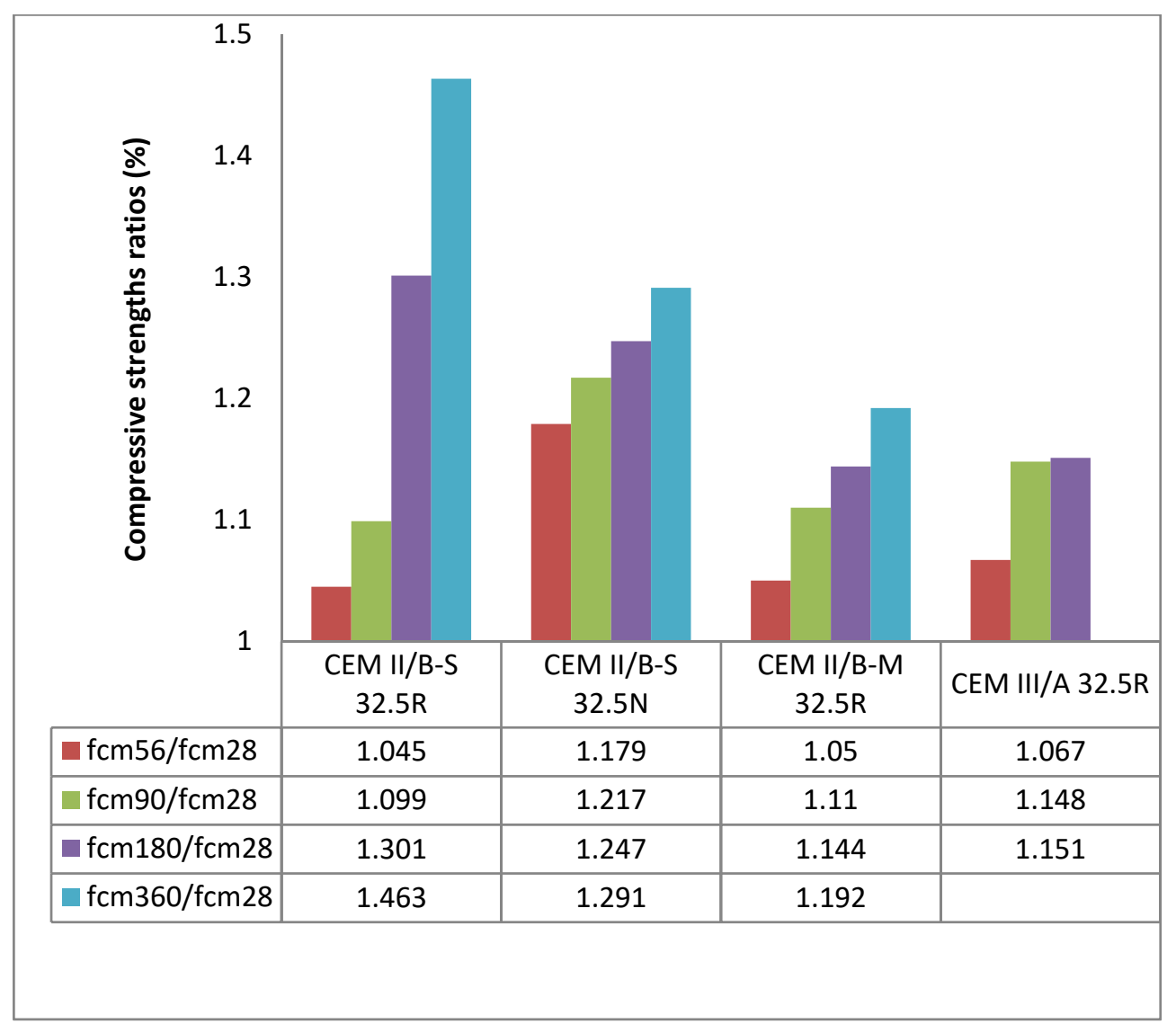

Fig. 6- Ratios between compressive strengths for concrete made with CEM II/B-S 32.5R, CEM II/B-S 32.5N, CEM II/B-M (S-V) 32.5R and CEM III/A 32.5R, depending on the type of cement and at a proposed reference time of 28 days.

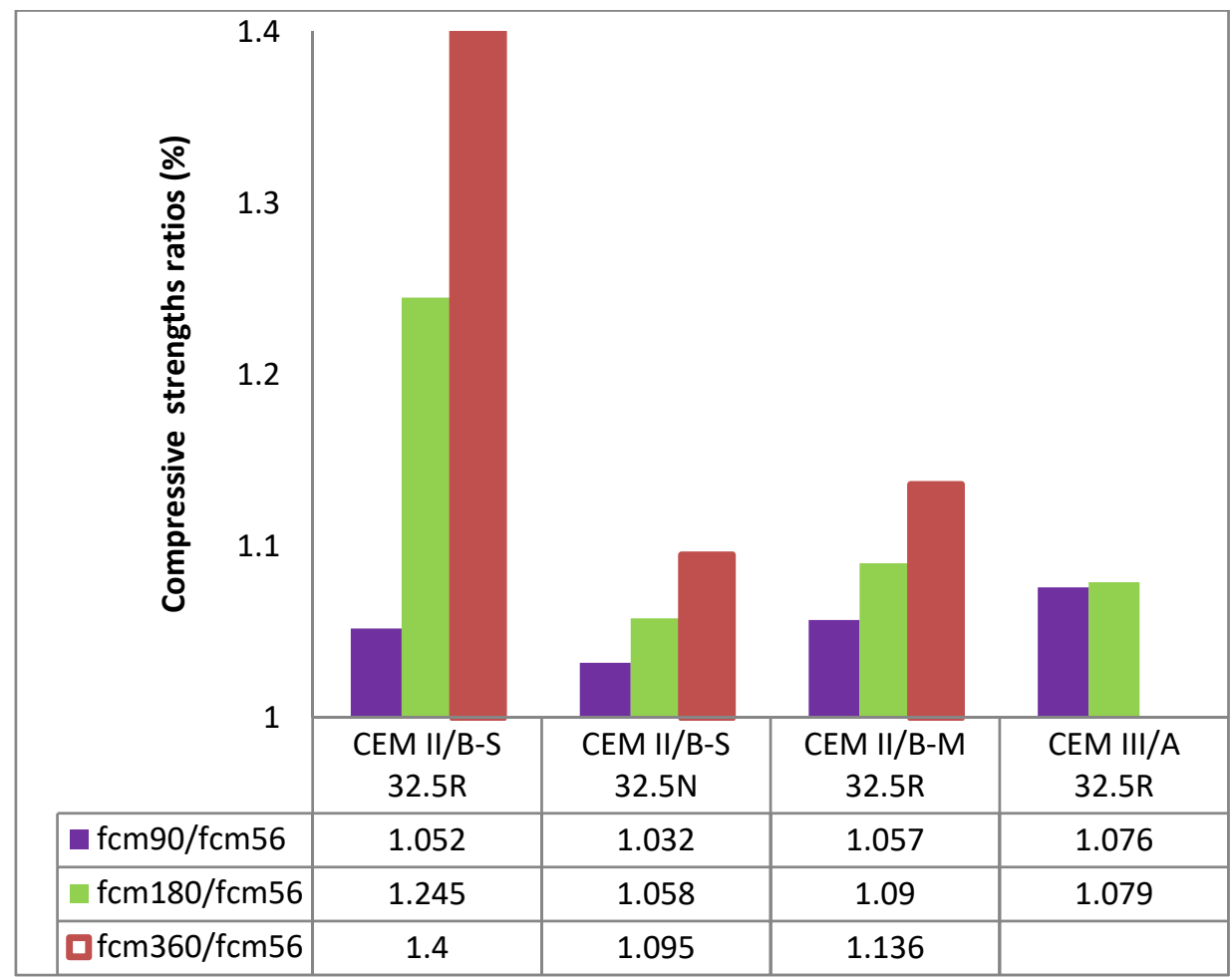

Fig. 7- Ratios between compressive strengths for concrete made with CEM II/B-S 32.5R, CEM II/B-S 32.5N, CEM II/B-M (S-V) 32.5R and CEM III/A 32.5R, depending on the type of cement and proposed reference time of 56 days. 


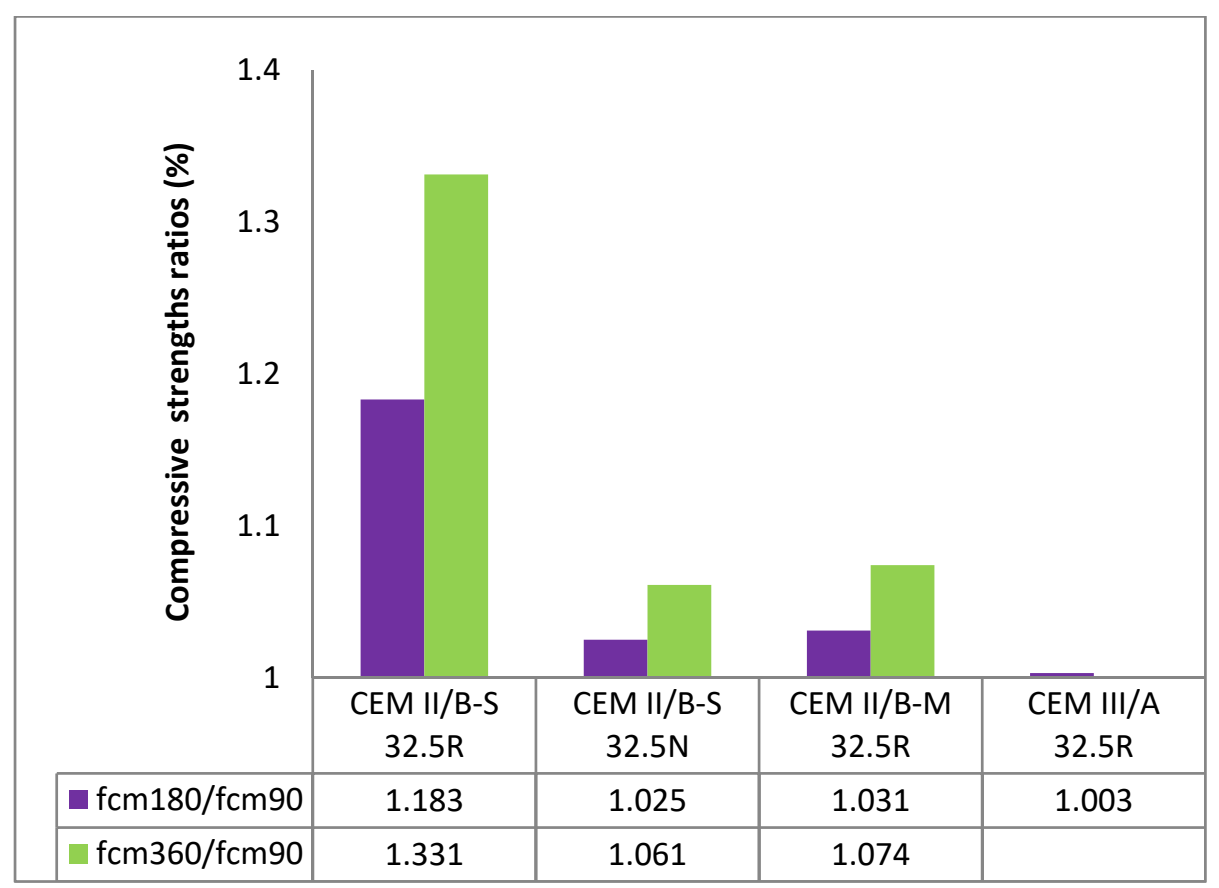

Fig. 8- Ratios between compressive strengths for concrete made with CEM II/B-S 32.5 R, CEM II/B-S 32.5 N, CEM II/B-M (S-V) $32.5 \mathrm{R}$ and CEM III/A $32.5 \mathrm{R}$, depending on the type of cement and proposed reference time of 90 days.

By studying the tables/figures we can observe that:

- - for concretes prepared with CEM II/B-S 32.5R, there is a significant difference between the evolution of actual compressive strengths and the calculated ones, regardless to the reference age, with a relatively small difference between the values of compressive strength at 28 and 90 days;

- for concretes prepared with CEM II/B-M 32.5R, the nearest reference value is at 90 days and shows a smaller difference between the actual and the computed results for compressive strength, but the difference between the results at 28 and 90 days is not significant;

- The evolution of average compressive strength for concretes with CEM II/B-S 32.5N experimentally obtained is nearly similar to the one obtained by applying the formulae but there is a major difference between the values at 28 days and at 90 days.

- In the case of concretes prepared with CEM III/A 32.5R, the average compressive strength at 90 days was $15 \%$ higher than at 28 days, but after this age there was no increase of average strengths, the nearest reference value being 56 days.

\section{Conclusions}

1. The studies shown in this article are an introduction in the field of analyzing the compression strength calculated for concrete of over 28 days of age, with a view to exemplifying and applying the knowledge from the new proposal issued in October 2017 in order to update the European standard prEN 1992-1-1 [2], to ensure the safety requirements for the exploitation of structures built with reinforced concrete prepared with cements containing mineral additions.

2. The reference time for determining concrete's class may be between 28 and 90 days in accordance with the draft revision prEN1992-1-1 [2]. 
3. The value of the "s"-coefficient, used for determining the compression strength of concrete at ages other than 28 days, is calculated as per the proposal of reviewing prEN1992-1-1 [2], according to the type of cement and the concrete's class - unlike the current edition, where "s" depends only on the type of cement (the strength at young ages and at 28 days).

4. This paper presents the results of the experimental research on concrete prepared with four types of cements containing slag in different proportions, one of type $\mathrm{N}$ and three of type $\mathrm{R}$, with similar w/c ratios, (where the concrete should have reached similar strengths).

5. The results obtained regarding the evolution over time of the compressive strengths show that the value of ,s" can not be considered the same based only on considerations in relation with the type of the cement characterized by its strength (eg 32.5R or N). For example, in the case of the concrete with CEM II/B-S 32.5R, there is a major difference between the actual evolution of strength and the one determined by using the formula proposed in the Draft for reviewing prEN1992-1-1 [2]. Also, in the case of concrete prepared with CEM II/B-S 32.5N cement, by applying the formula the reference age, should be 28 days. But there is an obvious difference between the results obtained at 28 days and 56 days respectively.

6. Therefore, a separate analysis is needed to experimentally determine the reference time/age for establishing the concrete's class, mainly depending on ratios between the strengths obtained at 56 days and 90 days, and 28 days respectively, and studying the evolution of concrete strength over time. If we obtain a strength at 56 or 90 an increase higher than $15 \%$ against the one at 28 days, and include in another concrete class (criterion fck +4 ), then a reference time higher than 28 days is proposed. Knowing the value of the reference time calculated this way, the formula proposed as per the Draft for revising prEN1992-1-1 [2] can be applied. Nevertheless, in such cases, trials/tests are recommended to be performed in order to determine the compression strength up to 1 year of age and to compare the actual evolution to the one obtained by applying the formula, In case of important differences, the „s" coefficient in the formula should be revised.

\section{References}

[1] SR EN 1992-1-1:2004 - Eurocode 2: Design of concrete structures - Part 1-1: General rules, rules for buildings, bridges and civil engineering structures;

[2] PT1prEN 1992-1-1:2017-10 - Eurocode 2: Design of concrete structures - Part 1-1: General rules, rules for buildings, bridges and civil engineering structures;

[3] SR EN 12350-1:2009 Test on fresh concrete. Part 1: Sampling

[4] SR EN 12390-2:2009 Test on hardened concrete. Part 2: Preparation and storage of test specimens for strength testing;

[5] SR EN 12390-3:2009 Test on hardened concrete. Part 3: Compression strength of specimens;

[6] Anca Ionescu - Research report no. 3 of the Doctoral Thesis - Experimental research for determining the optimal terms for the establishing the concrete characteristics made with cements with mineral additions. 